\title{
Pacyfizm jako bestseller. Na Zachodzie bez zmian i Józef Rotblat - dwa przypadki
}

\section{Pacifism as a bestseller. All Quiet on the Western Front and Joseph Rotblat - two cases}

\author{
|| Joanna Roszak
}

\begin{abstract}
The analysis of the most famous anti-war novel of all times, All Quiet on the Western Front by Erich Maria Remarque, a representative of a lost generation, becomes a pretext to compare the German author with Joseph Rotblat, a physicist born in Warsaw. They both found their own way to deal with the consequences of war. The first one, as a veteran of World War I and the author of the anti-war novels was nominated in 1931 for the Nobel Peace Prize, the second one was its laureate in 1995. While All Quiet on the Western Front is the novel most strongly related to the World War I, Rotblat, associated in Western Europe with calling for world peace and nuclear disarmament, is in Poland almost unknown and there is no information about him in the official teaching programs. This article is devoted to Remarque and Rotblat separate paths in practicing „militant pacifism”.
\end{abstract}

Key words: Joseph Rotblat, Erich Maria Remarque, pacifism

Streszczenie: Omówienie najsłynniejszej powieści antywojennej wszechczasów, Na Zachodzie bez zmian Ericha Marii Remarque'a, przedstawiciela lost generation, staje się pretekstem, by zestawić niemieckiego pisarza z urodzonym w Warszawie fizykiem, Józefem Rotblatem. Obaj znaleźli własną drogę, by walczyć z powikłaniami wojennymi. Pierwszego z nich, jako weterana wojny światowej z lat 1914-1918 i autora antywojennej powieści, nominowano w roku 1931 do Pokojowej Nagrody Nobla, drugi w 1995 został jej laureatem. O ile jednak Na Zachodzie bez zmian to powieść najsilniej powiązana asocjacyjnie z I wojną światową, o tyle Rotblat, kojarzony na zachodzie Europy z wieloletnimi działaniami nawołującymi do światowego pokoju i rozbrojenia nuklearnego, w Polsce jest niemal nieznany, a w szkolnych programach nauczania nie znaleziono dla niego miejsca. Artykuł poświęcony jest ich odrębnym drogom uprawiania „wojującego pacyfizmu”.

Słowa kluczowe: Józef Rotblat, Erich Maria Remarque, pacyfizm

Kiedy usłyszałam, że pańska organizacja nagrywa relacje świadków, od razu wiedziałam, że muszę do was przyjść. Skonała w moich ramionach, powtarzając: „Nie chcę umierać". Tak wygląda śmierć. Nie ma znaczenia, jakie mundury noszą żołnierze. Nie ma znaczenia, jak doskonała jest broń. Myślę, że gdyby wszyscy mogli zobaczyć to, co ja widziałam, nie byłoby więcej wojen (Foer 2007, 261). 
Te słowa Kinue Tomoyasu, mającej 44 lata, gdy wybuchła bomba zrzucona na Hiroszimę, są oskarżeniem każdej wojny i zachętą do pacyfizmu. Podobny efekt wywołała książka świadka i uczestnika wcześniejszej rzezi, mimo że on sam deklarował w swoistym do niej motcie: „Książka ta nie ma być oskarżeniem ani też wyznaniem. Ma tylko podjąć próbę udzielenia wieści o pokoleniu, które wojna zniszczyła - nawet gdy uchroniło się przed jej granatami" (Remarque 2004, 5). Pozbawiona heroizmu w opisach życia żołnierza powieść, o której tu mowa, Na Zachodzie bez zmian, ogłoszona „najsłynniejszą powieścią antywojenną wszechczasów” (Kowal 2011, 316), ukazuje „zachowania ludzkie w obliczu wojennego żywiołu” (Kowal 2011, 315). Wydano ją po polsku w przekładzie Stefana Napierskiego w 1930 roku. Grzegorz Kowal zanotował: „Napierskiemu przyszło zapłacić wysoką cenę za przekład powieści: według Czesława Miłosza i Władysława Bartoszewskiego aresztowanie, a następnie zabójstwo polskiego krytyka z rąk nazistów 2 kwietnia 1940 roku były efektem spolszczenia wyklętego w Trzeciej Rzeszy dzieła" (Kowal 2011, 318). W sytuacji szkolnej można omówić je w klasach licealnych o profilu rozszerzonym. Przy planowaniu cyklu lekcji warto jedną z nich poświęcić różnym obliczom pacyfizmu, mając przy tym okazję do prezentacji idei Józefa Rotblata, noblisty pokojowego urodzonego w 1908 roku w Warszawie.

Zarówno Remarque, jak i Rotblat znaleźli własną drogę, by walczyć z powikłaniami wojennymi, rozczarowaniem i lękiem. Pierwszy z nich stał się symbolem rozrzutności i ekstrawagancji (nosił monokl, wybierał osobliwe stylizacje, kolekcjonował drogie dzieła sztuki, przemieszczał się bugattim, romansował z Marleną Dietrich i Gretą Garbo), drugi zaś był uosobieniem prostoty i hojności. Remarque, przedstawiciel lost generation, spoglądał wstecz i wypowiadał się, między innymi, na temat praktyki leczenia weteranów wojennych, Rotblat natomiast spoglądał w przyszłość, informując ludzkość o możliwości „holokaustu nuklearnego” (Rotblat 2003). Pierwszego, jako weterana wojny światowej z lat 1914-1918 i autora antywojennej powieści, nominowano w roku 1931 do Pokojowej Nagrody Nobla, drugi w roku 1995 został jej laureatem. Jeden kupił tytuł szlachecki, drugi otrzymał go w 1996 roku.

O ile jednak $\mathrm{Na}$ Zachodzie bez zmian to powieść najsilniej powiązana asocjacyjnie z I wojną światową, o tyle Rotblat, kojarzony na zachodzie Europy z wieloletnimi działaniami nawołującymi do światowego pokoju i rozbrojenia nuklearnego, w Polsce jest niemal nieznany. W szkolnych programach nauczania nie znaleziono dla niego miejsca, mimo że mógłby i powinien stać się bohaterem i godziny wychowawczej, i chemii (choćby wtedy, gdy odbywa się w gimnazjum „sąd nad promieniowaniem”), i fizyki (był ukochanym uczniem Ludwika Wertensteina, spadkobiercy myśli Marii Skłodowskiej-Curie, współpracował z odkrywcą neutronu, Jamesem Chadwickiem, jego trajektoria biograficzna przecięła się z najtęższymi umysłami epoki). Remarque sprzedał milion egzemplarzy powieści w pół roku, 
rychło przetłumaczono ją na dwadzieścia dziewięć języków. Także Rotblat dokładał starań, by zareklamować ludzkości pacyfizm jako najwyższą ideę.

Erich Remarque urodził się w 22 czerwca 1898 roku w Osnabrück, w katolickiej rodzinie, jako syn introligatora i mechanika, Petera Franza, i jego żony, Anny Marii (w 1922 roku prawdopodobnie na jej cześć przybrał drugie imię „Maria”, choć niektórzy twierdzą, że to hommage dla Rainera Marii Rilkego). Objawiał talent pianistyczny, kolekcjonował motyle. 26 listopada 1916 roku, krótko po zdobyciu wysokich ocen w konkursie na esej, został wcielony do wojska. Budował bunkry, mierzył się ze snajperskim ogniem, uczestniczył w walkach I wojny światowej, jego przyjaciel zginął jak powieściowy Kat. Im Westen nichts Neues napisał kompulsywnie, w pięć tygodni, a drukował w odcinkach w czasopiśmie „Vossische Zeitung” od 10 listopada do 9 grudnia 1928 roku. Wydanie książkowe ukazało się w 1929.

Akcja powieści zaczyna się w 1917 roku po bitwie, która zdziesiątkowała oddział Paula Bäumera, narratora, zwerbowanego do wojska wraz z klasowymi kolegami przez nauczyciela, Kantorka. Pisał zatem Remarque, jak sam podkreślał w liście do sir Iana Hamiltona, z „wąskiej perspektywy” (Erich Maria Remarque. Wojujący pacyfista 1998, 43). Trafiając na front, jego bohaterowie mają (jak i on sam miał) osiemnaście lat, a ich ideały upadają w konfrontacji z okrucieństwem wojny. Żołnierz, od lata 1918 roku czekający na zakończenie wojny, został zabity w październiku, na tydzień przed zawieszeniem broni. Remarque, który stworzył powieść nie tyle antytyrtejską, co raczej - szerzej - pacyfistyczną, zainspirował masowy ruch pokojowy, a adaptacja All Quiet on the Western Front w reżyserii Lewisa Milestone’a zdobyła Oscara za najlepszy film w 1931 roku. Warto przypomnieć odpowiedź Remarque’a na zakaz rozpowszechniania obrazu w Niemczech: „Należy (...) z całą stanowczością przeciwstawiać się (...) gloryfikowaniu wojny i bagatelizowaniu bezgranicznej nędzy, jaką wojna spowodowała" (Cyt. za: Erich Maria Remarque. Wojujacy... 1998, 6). Zamknął wypowiedź cytatem z „opublikowanej właśnie nowej książki (...) Droga powrotna: «Dziedzictwo zmarłych nie zawiera się w słowie zemsta - ale w nigdy więcej»" (Erich Maria Remarque. Wojujący... 1998, 6). Dwa lata później powieść została spalona przed berlińską operą wraz z książkami Thomasa Manna, Ernesta Hemingwaya, Bertolta Brechta czy Alberta Einsteina. W 1938 roku jej autor utracił niemieckie obywatelstwo (od roku 1932 mieszkał w Szwajcarii, od 1939 w USA).

Powróćmy do wymowy motta, o którym Grzegorz Kowal napisał:

Duże znaczenie przypisuje się samemu mottu książki, nawet jeśli Remarque w wywiadach konsekwentnie odżegnywał się od jego pacyfistycznego wydźwięku. Znany był jego deklarowany powszechnie dystans wobec świata polityki. (...) nie opowiadając się zdecydowanie po żadnej ze stron, ani przeciwko wojnie, ani za wojną, nie zawężał grupy potencjalnych odbiorców swojej książki. To dlatego czytelnikami powieści byli zarówno weterani wojenni, jak i nacjonaliści, komuniści i - rzecz jasna - pacyfiści. Ów dystans Remarque’a wobec świata polityki odsłonił 
z biegiem czasu również swoją ciemną stronę: w przeciwieństwie do pozostałych emigrantów niemieckich Remarque potrzebował aż kilkunastu lat, by dopiero w wydanej po wojnie powieści Łuk triumfalny zająć zdecydowane stanowisko i opowiedzieć się przeciwko Hitlerowi oraz nazizmowi (Kowal 2011, 326).

Badacz dodał:

choćby nawet żaden z bohaterów powieści nie zdecydował się na wypowiedzenie słów „Nigdy więcej wojny”, to uczynią to w zastępstwie (co wcale nie znaczy, że mniej sugestywnie) apokaliptyczne obrazy, ukazujące piekło wojny i tragiczną śmierć, masową rzeź ludzi i zwierząt (Kowal 2011, 327).

Germanista zaakcentował zespolenie dzieła i życia autora, wszak Paweł Bäumer i Erich Maria Remarque „to jedna i ta sama osoba, nawet jeśli Remarque z wojny powraca, a Bäumer w jej ostatnich dniach ginie" (Kowal 2011, 327).

Nastroje antywojenne nasilają się, gdy czytelnik konfrontuje się z obrazami amputacji, podgląda żołnierzy jedzących w brudzie smażoną koninę, gdy czyta o obrazach z lazaretu, żołnierzach „zatrutych gazem, którzy w dławieniu, trwającym całe dnie, rzygają kawałkami spalonych płuc" (Remarque 2004, 41) albo relację $\mathrm{z}$ narratorem zbiorowym: „nie mamy już mięsa ani muskułów, nie możemy już patrzeć na siebie z trwogi przed czymś nieobliczalnym. Więc oto zaciskamy siłą wargi... to minie... to minie... może jakoś uda się nam z tym uporać" (Remarque 2004, 64). W wywiadzie prowadzonym przez Axela Eggebrechta Remarque dokonywał metatematycznego podsumowania: „Mówiłem tylko o przeżywanej przez wszystkich okropności, o grozie, o rozpaczliwym, nierzadko prymitywnym instynkcie samozachowawczym, o uporczywej sile życia, które przeciwstawia się śmierci i zagładzie" (Erich Maria Remarque. Wojujacy..., 35).

W 2005 roku zmarł z poczuciem spełnienia inny człowiek dążący do prawdy i kochający ludzkość. Człowiek, który uważał, że jego jedyną bronią są słowa; który nie umiał się nad sobą użalać - optymista z wyboru i Brytyjczyk z wyboru, nieumiejący iść na ustępstwa, przez co nierzadko narażał się na przykrości. Swoim mottem uczynił parafrazę starożytnej sentencji: „Si vis pacem, para bellum”, mawiał bowiem: „Si vis pacem, para pacem". Chcesz pokoju, przygotuj się na niego. Całym życiem potwierdził słowa Ghandiego: „moc ludzkiego ducha jest silniejsza niż broń nuklearna”. Rotblat, jak strażnik, zgodnie ze znaczeniem jego nazwiska, pokazywał czerwoną kartkę zawsze wtedy, gdy przeczuwał nową katastrofę; niezmordowanie budował kulturę pokoju.

Trudno uwierzyć, że w jednym życiu można zmieścić tyle pasjonujących opowieści, i dramatycznych, i podnoszących na duchu: miłosną, kryminalną i sensacyjną. Ale nade wszystko historia Józefa Rotblata to historia dzielnego człowieka, który w 1945 roku stracił wszystko, w czym pokładał bezgraniczne nadzieje: żonę, a po ataku na Hiroszimę i Nagasaki także wiarę w naukę oraz sumienie naukowców. 
Ten wojujący pacyfista, z urodzenia warszawiak, Polak żydowskiego pochodzenia, drugą wojnę przeżył częściowo w Anglii, jako młody doktor, fizyk, współpracownik noblisty, Jamesa Chadwicka. Był jedynym naukowcem nie-Anglikiem i nie-Amerykaninem, zaproszonym do Projektu Manhattan, któremu pozwolono na niezmienianie obywatelstwa. Był też jedynym, który projekt porzucił, gdy stało się jasne, że hitlerowskie Niemcy jednak nie zbudują własnej bomby. Po wojnie zmienił trajektorię zawodową i postanowił wykorzystać promieniowanie w medycynie, będąc pionierem gałęzi medycyny fizycznej. Zamieszkał w Londynie, gdzie do emerytury pracował w Szpitalu św. Bartłomieja.

W 1955 roku stał się jednym z jedenastu sygnatariuszy Manifestu Russella-Einsteina (wraz z Albertem Einsteinem, Bertrandem Russellem, Frederikiem Joliotem-Curie, Maksem Borem, Linusem Paulingiem, Hidekim Yukawą, polskim fizykiem, swoim byłym wykładowcą - Leopoldem Infeldem), dwa lata później współzałożył ruch Pugwash w Sprawie Nauki i Problemów Światowych, wraz z którym w 1995 roku otrzymał Pokojową Nagrodę Nobla. Pierwszy raz norweski komitet podzielił ją między organizację i indywidualnego człowieka. W jednym z biur ruchu wisiały żurawie z origami, symbole pokoju, jakie Józef Rotblat otrzymał od japońskich dzieci.

Po tym, jak królowa przyznała mu tytuł szlachecki, został zaproszony do udziału w audycji radia BBC, w której opowieść o życiu miał ilustrować ulubioną muzyką. Wybrał m.in. Last Night I Had the Strangest Dream (Poprzedniej nocy miałem dziwny sen) Pete'a Seegera, nieformalny hymn wielu ruchów pacyfistycznych, w którym wszyscy ludzie zgodzili się, by położyć kres wojnie i w potężnym pokoju podpisali dokument, głoszący, że już nigdy nie będą walczyć; zaś kiedy wykonali milion kopii, złączyli ręce, pochylili się, zmówili modlitwę wdzięczności, tańczyli na ulicach, rzucając na ziemię miecze, pistolety i mundury.

Last night I had the strangest dream

I ever dreamed before

I dreamed the world had all agreed

To put an end to war

I dreamed I saw a mighty room

The room was filled with men

And the paper they were signing said

They'd never fight again.

Jakie wydarzenia uczyniły Rotblata pacyfistą? Pierwszym z nich była właśnie wojna lat 1914-1918, która przerwała rodzinną idyllę. Z przyczyn finansowych ojciec, Zalman Rotblat, w 1914 roku był zmuszony przeprowadzić rodzinę z warszawskiej willi przy ulicy Miłej - na Nowolipki 53. Nastały jałowe lata. Konie ojca zarekwirowała niemiecka armia, nie dając jakiejkolwiek rekompensaty, zerwane zostały jego umowy z Finlandią - stamtąd transportował papier do warszawskich drukarni. Rodzina Rotblatów 
nagle popadła w ubóstwo, wszystkie dogodności znikły, często doświadczali głodu, a podstawą menu stały się rozmrażane ziemniaki. Jego dzieciństwo zostało zrujnowane przez wojnę; miał być przez nią okradziony jeszcze raz, a jego pełne zaangażowanie w walkę o pokój można postrzegać jako egzorcyzmy nad własnymi wojennymi stratami (analogonem dla działań pacyfistycznych - w przypadku Remarque'a - stało się pisanie i uczestniczenie w sesjach terapeutycznych u cenionej Karen Horney). Jego żona, Tola, zginęła w Bełżcu; bomba, nad którą pracował w Los Alamos, by zapobiec światowej tragedii, została zrzucona na Hiroszimę po tym, jak Rotblat zabiegał o zamknięcie angielsko-amerykańskiego projektu.

Wszystkie doświadczenia wojenne uczyniły z niego człowieka, który prowadził kampanię dla pokoju, zadedykował mu życie i osiągnął sukces, nie idąc na kompromis. Drogą walki o pokój i rozbrojenie nuklearne kroczył konsekwentnie od porzucenia Projektu Manhattan.

Ten jeden z najzdolniejszych polskich fizyków XX wieku przede wszystkim polecał jako lekturę Krótka historię czasu Stephena W. Hawkinga. 3 października 2004 na Trafalgar Square jako najstarszy manifestujący ramię $\mathrm{w}$ ramię $\mathrm{z}$ Hawkingiem sprzeciwiał się wojnie w Iraku. Odczytano wówczas pięć tysięcy znanych nazwisk irackich mężczyzn, kobiet i dzieci, które zginęły w konflikcie. Udział w pikiecie wzięli też noblista literacki Harold Pinter, aktorka Juliet Stevenson, mer Londynu, Ken Livingstone, i bliscy poległych w Iraku brytyjskich żołnierzy.

W przemówieniu noblowskim przypominał Manifest Russella-Einsteina:

Nie mamy wyboru. Alternatywa jest nie do przyjęcia. Pozwolę sobie zacytować ostatni akapit manifestu Russella-Einsteina:

Apelujemy, jako ludzie, do ludzi: pamiętajcie o swoim człowieczeństwie i zapomnijcie o reszcie. Jeśli możecie to zrobić, otwiera się droga do nowego raju; jeśli nie możecie, znajdziecie tam drogę ryzyka powszechnej śmierci.

Dążenie do świata bez wojny ma podstawowy cel: przetrwanie. Ale jeśli w tym procesie dowiadujemy się, jak osiągnąć to przez miłość, a nie przez strach, przez życzliwość, a nie przymus; jeśli w tym procesie uczymy się łączyć niezbędne z przyjemnym, stosowne z dobroczynnym, praktyczne z pięknym, będzie to dodatkowy bodziec do podejmowania tego wielkiego zadania.

Przede wszystkim, pamiętajcie o swoim człowieczeństwie (wykład noblowski J. Rotblata, przeł. J. R.)

Wiele ze zdań autora Na Zachodzie bez zmian Józef Rotblat uważałby za celne: „Wojny nie jest w stanie uprawomocnić nawet poważne naruszenie samej sprawiedliwości" (Erich Maria Remarque. Wojujący..., 49). Znajdziemy też takie, które charakteryzują tę charyzmatyczną postać i przypominają coraz aktualniejszą prawdę: „Zapominają (...), że w naszych niespokojnych czasach bojownik demonstruje mniejszą odwagę od tego, który waży się zwać pacyfistą" (Erich Maria Remarque. Wojujący..., 51). 


\section{Propozycje działań lekcyjnych}

\section{Droga Tolu. Szanowny Noblisto.}

(propozycje dla szkoły gimnazjalnej)

Lekcja wprowadza młodzież w świat życia i dokonań Józefa Rotblata. Po 45 minutach uczestniczki i uczestnicy porządkują fakty biograficzne, budują sieć powiązań między Rotblatem a innymi noblistami, także polskimi. Jednostka lekcyjna służy również wskazaniu autorytetu, inspiruje młodzież do twórczych poszukiwań i pięknego życia, wzmacnia motywację do działań na rzecz własnego rozwoju i dobra świata.

Przebieg lekcji (wszystkim punktom towarzyszy prezentacja multimedialna):

1. Nauczyciel otwiera pogadankę na temat gwiazd i autorytetów (dostrzeżenie różnicy między nimi).

2. Ukierunkowuje rozmowę na temat marki osobistej.

3. Nauczyciel moderuje krótki dialog poświęcony imionom - czy zostały nadane na cześć ważnych dla rodziców postaci?

4. Prowadzący pyta, czy wśród uczestników znajduje się chłopiec o imieniu Józef i odczytuje inspirujący fragment listu Sandry Iono Butcher - współpracowniczki Józefa Rotblata z ruchu Pugwash - do jej syna, Joe'ego, noszącego imię na cześć profesora.

Mój kochany synku, Joseph to imię, które powinieneś nosić z dumą. Bądź buntownikiem w dobrej sprawie. Nie czuj się ograniczony przez ograniczenia nałożone na Ciebie przez innych. Traktuj innych z godnością i lojalnością. Rozciągaj umysł i otwieraj serce. Domagaj się sprawiedliwego świata i szukaj pokoju w każdej sytuacji. Odmawiaj kompromisu, który kazałby Ci porzucić Twoje wartości. Śmiej się z innymi. Żyj prosto i ze znaczeniem. Nie oceniaj ludzi po ich tytułach lub wieku, ale przez pryzmat ich kreatywności i żywotności. Wyobraź sobie długie i twórcze życie, a następnie przekraczaj te oczekiwania. Jeśli zrobisz wszystkie z tych rzeczy, będziesz szanować przykład dany przez Józefa Rotblata (przeł. J. R.).

5. Nauczyciel prezentuje postać Józefa Rotblata, kreśląc najważniejsze fakty z jego życia:

- urodzony w żydowskiej rodzinie w Warszawie (krótka rozmowa o zwyczajach żydowskich, języku jidysz, którym posługiwała się rodzina Rotblata),

- samouk, a następnie jeden z najzdolniejszych uczniów Wolnej Wszechnicy,

- ślub z Tolą Gryn,

- wyjazd na stypendium zagraniczne do Liverpoolu,

- wybuch wojny - śmierć żony w komorze gazowej, przetrwanie reszty rodziny w getcie warszawskim i kryjówce w Otwocku,

- praca nad bombą atomową, 
- porzucenie projektu Manhattan z pobudek etycznych,

- wstrząs po wiadomości o zrzuceniu bomby na Hiroszimę i o śmierci żony,

- $\quad$ zmiana specjalizacji badań - pracownik szpitala św. Bartłomieja w Londynie, w departamencie fizyki medycznej,

- „pamiętaj o swym człowieczeństwie” - założenie organizacji Pugwash,

- Pokojowa Nagroda Nobla w 1995 roku.

6. Rozmowa o tym, co determinowało życie Józefa Rotblata.

7. Podsumowanie: nauczyciel eksponuje charyzmatyczne i godne naśladowania cechy Józefa Rotblata, budujące jego „markę osobistą”, oraz podkreśla jego konsekwencję w prowadzeniu działań na rzecz pokoju i rozbrojenia nuklearnego.

Dalsza część lekcji lub druga jednostka lekcyjna może zostać zainspirowana akcją związaną z Heniem Żytomirskim, urodzonym w 1933 roku przy ulicy Szewskiej 3 w Lublinie. Ostatnią fotografię chłopca wykonano w maju 1939, na jednej z ulic. We wrześniu miał pójść do pierwszej klasy szkoły podstawowej, ale zginął w komorze gazowej na Majdanku w listopadzie 1942 roku. Pracownicy Ośrodka „Brama Grodzka - Teatr NN” w Lublinie zorganizowali akcję Listy do Henia. Inspirując się tym działaniem, proponuję napisanie listów do Józefa Rotblata lub pochodzącej z Lublina i zgładzonej w Bełżcu Toli Rotblat, a następnie odczytanie ich i dyskusję o ich zawartości, życiu z syndromem Ocalonego oraz sposobach opowiadania o Holokauście.

\section{II. Żurawie z origami. Rozbrajanie}

(1,5 h, lekcja języka polskiego lub godzina wychowawcza przeznaczona dla szkoły gimnazjalnej bądź licealnej)

W miastach o dziwacznych nazwach

grad ołowiu, grzmot żelaza:

nieświadomi, co ich wina, ludzie gina.

Josif Brodski, Piosenka o Bośni, przeł. Stanisław Barańczak

Warsztat opiera się na historii Sadaki Sasaki, która urodziła się w styczniu 1943 roku. Miała dwa lata, gdy 6 sierpnia 1945 roku Mały Chłopiec, bomba zrzucona na Hiroszimę, odmieniła życie małej dziewczynki, spadając niedaleko jej domu położonego przy Moście Misasa. Zginęła wówczas jej babcia. Sadako hodowała wiele marzeń, ale wśród nich największe: zostać mistrzynią w bieganiu. Zapewne wzięłaby udział w tokijskim maratonie, jednym z największych na świecie. Gdy miała 11 lat, dowiedziała się, że cierpi na białaczkę popromienną.

Ponieważ japońska legenda mówi, że żurawie żyją tysiąc lat, Sadako postanowiła złożyć tysiąc żurawi - symbolizujących pokój i zdrowie. 
Podobno zmarła przy 644., 25 października 1955 roku. Jej przyjaciele złożyli brakujące 356 origami i pochowali ją z tysiącem papierowych ptaków. Trzy lata później w parku w Hiroszimie powstał jej pomnik. Zdobi go napis: „To nasz płacz, to nasza modlitwa, pokój na świecie”. Kto pragnie dołączyć się do tej modlitwy, w rocznicę ataku na Hiroszimę składa papierowe ptaki. Takie żurawie dostał Józef Rotblat od japońskich dzieci. Wisiały w biurze organizacji Pugwash.

Podczas lekcji proponuję pokazać film animowany poświęcony dziewczynce z Hiroszimy, przeprowadzić dyskusję sprowokowaną wierszem Josifa Brodskiego Piosenka o Bośni, fragmentem powieści Jonathana Safrana Foera Strasznie głośno, niesamowicie blisko oraz zorganizować warsztat analizy i interpretacji wierszy związanych z Hiroszimą (np. Rzeczywistość wymaga Wisławy Szymborskiej). W zależności od temperamentu klasy, można zaproponować pisanie zainspirowanych ideą pacyfizmu haiku.

$\mathrm{Na}$ koniec warto przeznaczyć kwadrans na naukę składania z młodzieżą żurawi z origiami, symbolu pokoju w Hiroszimie (potrzebne rekwizyty: kolorowy, miękki papier w kształcie kwadratu, arkusz dla każdego uczestnika/każdej uczestniczki). Mogą one stać się ozdobą klasy. Młodzież może napisać na nich swoje haiku bądź prośby o pokój.

\section{Bibliografia}

Antkowiak Alfred, 1995, Erich Maria Remarque, Berlin.

Brodski Josif, 2006, Piosenka o Bośni, Barańczak S. (przeł.), w: Tym tylko byłem, Illg J. (wybór wierszy i posł.), Kraków, s. 165-166.

Butcher Sandra, 2007, An open letter tomy son on the death of. Joseph Rotblat, w: Joseph Rotblat: Visionary for Peace, ed. by: Braun R., Hinde R., Krieger D., Kroto H., Milne S., London, s. 111-118.

Dziergwa Roman, 2003, Nauczyciel i żołnierz jako moralista, „Polonistyka”, nr 6.

Erich Maria Remarque. Wojujacy pacyfista. Artykuły i wywiady 1926-1966, 1998, Schneider T. F. (wybór i wstęp), Kunicki W. (przeł.), Warszawa.

Foer Jonathan Safran, 2007, Strasznie głośno, niesamowicie blisko, Batko Z. (przeł.), Warszawa.

Kowal Grzegorz, 2011, Piekło na ziemi, w: Arcydzieła literatury niemieckojęzycznej. Szkice, komentarze, interpretacje, tom II, Białek E., Kowal G. (red.), Wrocław.

Pajewski Janusz, 2004, Pierwsza wojna światowa 1914-1918, Warszawa.

Remarque Erich Maria, 2004, Na Zachodzie bez zmian, Napierski S. (przeł.), Poznań.

Rotblat Joseph, 2003, Reunion in Pugwash, referat otrzymany w maszynopisie. Tims Hilton, 2007, Erich Maria Remarque. Ostatni romantyk, Słysz M. (przeł.), Warszawa. 
Wagener Hans, 1991, Understanding Erich Maria Remarque, Hampton.

Erich Maria Remarque's All Quiet on the Western Front. Critical Interpretations, 2009, ed. by: H. Bloom, New York.

\section{O Autorce:}

Joanna Roszak - adiunkt w Instytucie Slawistyki PAN. W lutym 2016 współufundowała Fundacje Józefa Rotblata i została jej wiceprezeską. Poetka, inicjatorka wielu akcji dla młodzieży gimnazjalnej i licealnej. Ostatnio wydała Miejsce i imię. Poeci niemieckojęzyczni $\dot{z y d o w s k i e g o ~ p o c h o-~}$ dzenia oraz Słyszysz? Synagoga. Wychodzac spod poznańskiej synagogi przy Wronieckiej. Przygotowuje książkę poświęconą Józefowi Rotblatowi i jego rodzinie. 